DOI: $10.15193 /$ zntj/2018/117/257

\author{
ELENA HORSKÁ, PETER ŠEDÍK, JAKUB BERČÍK, \\ ANDRZEJ KRASNODĘBSKI, MARIUSZ WITCZAK, \\ AGNIESZKA FILIPIAK-FLORKIEWICZ
}

\title{
AROMACHOLOGY IN FOOD SECTOR - ASPECTS OF CONSUMER FOOD PRODUCTS CHOICE
}

\begin{abstract}
S u m m a r y
A current therapy trend known as ,back to nature therapy” boosts the use of essential oils and pure fragrance compounds and increases the importance thereof not only in medicine, but also in the business sphere. Marketing services involving aroma applications include for example scent logo or corporate aroma, selecting air-scent for interiors that strongly depends on the type of industry, scents used during marketing campaigns, corporate events or in outlets as those scents impact customer behaviour. In the paper there was presented a review of the reference literature on the aroma usage in food retail outlets. There was discussed the effect of aromas on the behaviours and emotions of consumers and on their perception of the environment as was the effect of aromas on the likelihood of purchase, the amount of money spent, and the evaluation of products and the outlet. It was showed that the scent applied had a positive effect on the shoppers and customers, incl. their moods, behaviours and emotions. Regarding the type of aroma, the analysis covered mostly the floral and food-based scents incl. citrus and herbal scents. It was proved that following the category-congruent olfactory cues had a positive effect on the sales of the entire product range. In general it can be inferred that modifying the environment by adding appropriate aromas has a positive effect on customers, and this can be a high potential for the food sector and for other sectors of the business sphere.
\end{abstract}

Key words: aromachology, aroma compounds, food products, points of sale, consumer behaviour

Prof. Dr. Ing. E. Horská, Ing. P. Šedik, Ing. PhD. J. Berčík, Faculty of Economics and Management, Slovak University of Agriculture in Nitra, Tr. A. Hlinku 2, 94976 Nitra, Slovakia, dr hab. inż. A. Krasnodębski, Instytut Ekonomiki i Zarzadzania Przedsiębiorstwami, Wydz. Rolniczo-Ekonomiczny, Uniwersytet Rolniczy w Krakowie, ul. Mickiewicza 21, 31-120 Kraków, dr hab. inż. M. Witczak, Katedra Inżynierii i Aparatury Przemystu Spożywczego, dr hab. inż. A. Filipiak-Florkiewicz, prof. nadzw., Katedra Technologii Gastronomicznej i Konsumpcji, Wydz. Technologii Żywności, Uniwersytet Rolniczy w Krakowie, ul. Balicka 122, 30-149 Kraków.Kontakt: elena.horska@gmail.com 


\section{Introduction}

A therapy trend „back to nature therapy“ boosts the use of essential oils and pure fragrance compounds and the importance thereof not only in medicine and cosmetics, but also in the business sphere. In science there are two terms linked with this subject matter: aromatherapy and aromachology. Even with various research methodologies and directions, it is difficult to clearly specify major differences between those two terms because of their interconnection and evident relationship [50].

The term "aromatherapy" was invented in 1920 by Gattefosse, a French chemist, who worked in the cosmetic industry and deeply understood the importance of antiseptic properties of essential oils and their permeability through skin [8]. Another definition was suggested by Bauchbauer [7], who described the word "aromatherapy" as a therapeutic application of essential oils, which cure or mitigate infections and diseases by means of inhalation. After 1980 the phenomenon of aromatherapy diversified into several spheres: medical aromatherapy (France), esoteric aromatherapy (Western countries), aromatherapy massage (Great Britain) and applied science sponsored by the Fragrance Research Fund [10]. In fact essential oils are secondary metabolites [5], which represent a complex mixture of volatile compounds found in aromatic plants [51]. In total there are approximately 3000 essential oils from more than 2000 various plants [24]. Several research studies have pointed out that the essential oils and their therapeutic effects are becoming more common worldwide $[14,37,44]$ in the complementary and alternative medicine [13]. In addition, the essential oils are used in food industry as both the additives and the biological packaging materials [41]; they are even used in air quality control in indoor environments [52].

The second term "aromachology"' was invented in 1982; it is a science that studies psychological and physiological effects of inhaling aromas and examines, with the use of fragrance technology, feelings and emotions elicited by odours stimulating olfactory pathways. The specific results obtained confirm that inhaling aromas may elicit relaxation, sensuality, happiness or exhilaration $[8,47,50]$. Also all the above mentioned outcomes could be applied in the complementary and alternative medicine in terms of maintaining mental health and rehabilitation effects [29]. According to Wang and Chen [50] several research studies were conducted in Europe, Japan and USA to explore relationships between the effects of fragrance and human emotions, feelings and moods. Moreover, few studies researched the effects of fragrance on the cognitive function, skin conductance, and involuntary or voluntary behaviour. Several correlations between some effects of various essential oils and human emotions are shown in Fig. 1. For example the effects of basil, jasmine and pine are correlated with mania, whereas those of camphor and balm oil with stimulation. The sedative effect of lavender oil is associated with distrustfulness, irritability, tension and melancholy. 
Another study indicates that the oil of 'lavandin', a hybrid of lavender, decreases fatigue and confusion [47]. Moreover, there is a strong relationship between the emotional response and the quality of fragrance used and also a strong correlation between the hedonic tone of fragrance (pleasant) and positive emotions [48].

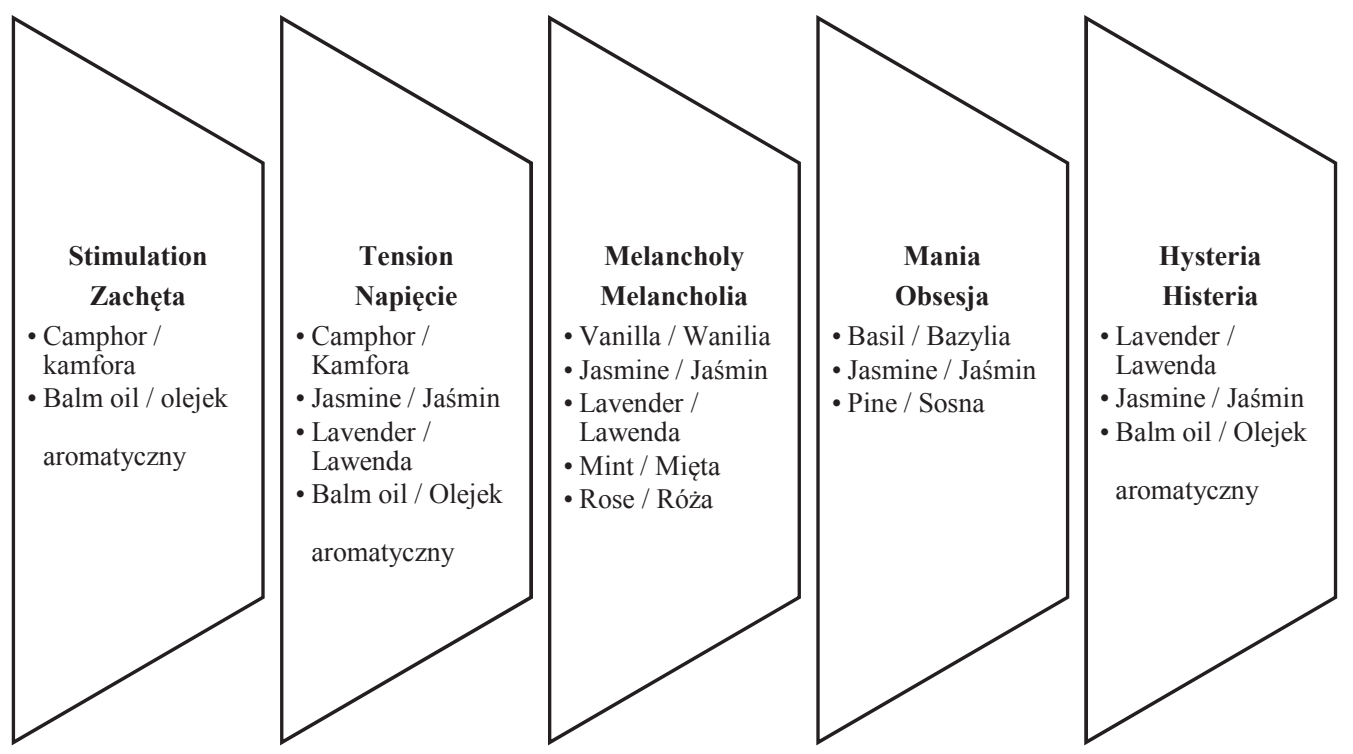

Fig. 1. Emotions evoked by sedative essential oils

Rys. 1. Emocje wywoływane przez olejki eteryczne o działaniu uspokajającym

Source / Źródło: the authors' own study based on [50] / opracowanie własne na podstawie [50]

\section{Reference literature review methodology}

The major objective of the paper was to make a review of available reference literature on the applications of scent in the food sector and on the impact of scent on the consumer behaviour (Fig. 2), emotions, and perception of the environment.

The reference literature review comprises mostly of the scientific papers registered in the Web of Science and Scopus databases. A method of comparison was used in order to achieve the main objective of the paper. In the paper opinions and attitudes are compared as are results of the field research on the applications of scent in various sectors. The section 'Results' contains the review of various opinions on the behavioural response to scent followed by the comparison of different field studies in the business sphere including food sector and by the analysis of applications of different types of scents in various business facilities. 


\section{Results of the reference literature review}

Marketing services connected with aroma applications generally involve the following aspects: scent logo or corporate aroma, selecting air-scent for interiors that strongly depends on the type of industry, scents used during marketing campaigns or corporate events, scents in the points of sale as they impact the customer behaviour [1, 2]. Speaking generally scents can have an effect on the evaluation of products and on the environment, where foods are sold, such as restaurants, markets and other food facilities [21, 38]. According to Vysekalová [49] the appropriate intensity of scents increases positive emotions, which may strengthen the memory of purchase (Fig. 2).

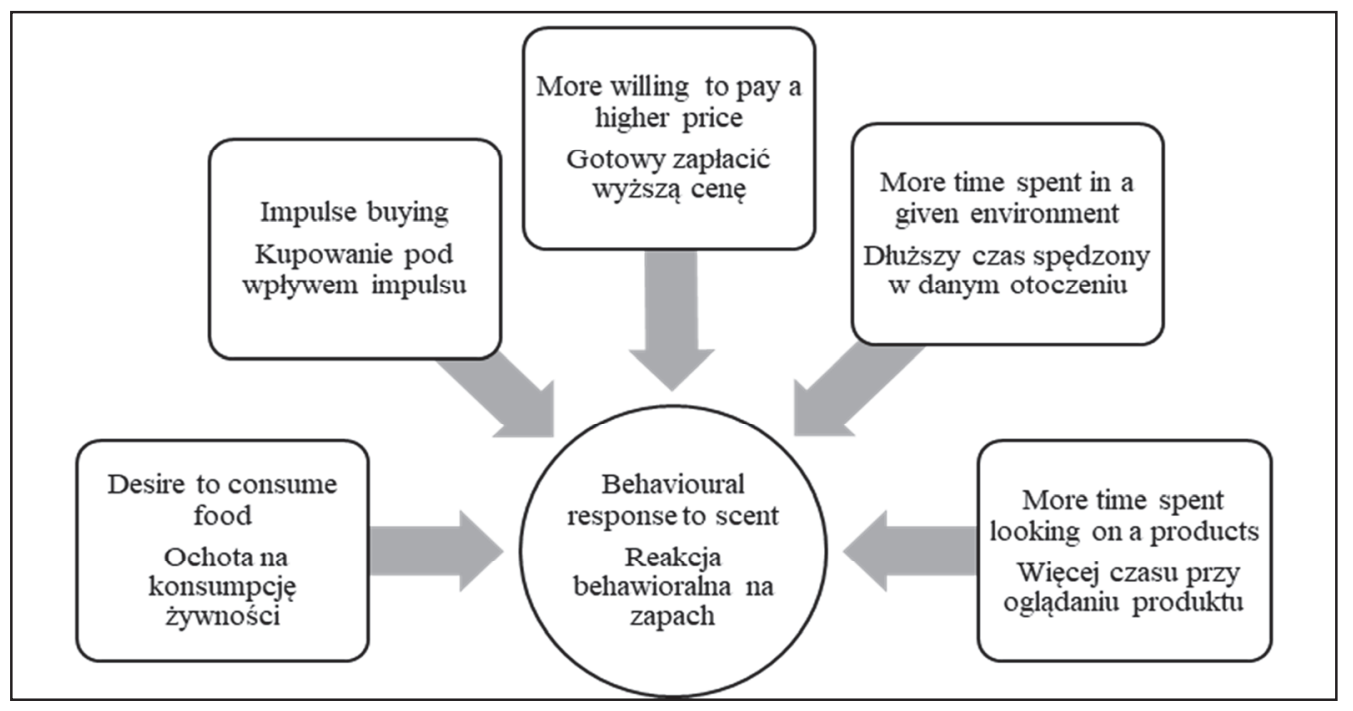

Fig. 2. Effects of scent on consumer behaviour

Rys. 2. Wpływ zapachu na zachowania konsumenckie

Source / Źródło: the authors' own study based on [42] / opracowanie własne na podstawie [42]

In terms of the food sector, consumers have experienced food smells since their birthday, during almost every process of consuming foods, where the appetite for matching products increases owing to olfactory food cues. For example savoury aromas decrease the appetite for sweet foods and increase it for spicy foods [40, 43, 53]. In other research studies in the food sector, there was analyzed the impact of some selected food smells on the consumer's appetite. The results obtained showed that the smells perceived had certain effects on choosing foods by the participants. It was proved that the pear aroma had a positive effect on selecting fruity desserts while the aroma of pizza increased the consumption of savoury food products including pizza itself $[18,19,20]$. According to Zoon et al. [53], the aroma of freshly baked bread 
tempts customers to purchase a bread loaf and to eat it. Similar results were obtained in the research study conducted in Slovakia; the Slovakian study results confirmed that the aromatic compounds (crunchy bread aroma) had a certain effect on the quantity of baked baguettes (Paninis) sold [4]. Moreover, retailers can affect the behaviour and attitudes of consumers by applying an ambient scent technology [6]. Several studies indicate that the similarities among the features of products are essential for customers and help them categorize the products; they can also improve their evaluations and purchase intentions $[9,17,34,39]$. The scent is easy to process provided it is congruent with a product category [22]. This idea is supported by the field studies conducted in six hypermarkets by applying the aroma of chocolate congruent with the whole product

Table 1. Studies on effects of ambient scents

Tabela 1. Badania dotyczące wpływu zapachów otoczenia

\begin{tabular}{|c|c|c|}
\hline $\begin{array}{c}\text { Sample } \\
\text { Próba }\end{array}$ & $\begin{array}{c}\text { Research context } \\
\text { Kontekst badawczy }\end{array}$ & $\begin{array}{l}\text { Authors } \\
\text { Autorzy }\end{array}$ \\
\hline $\begin{array}{l}\text { Slot players at } 18 \text { slot } \\
\text { machines } \\
\text { Gracze przy } 18 \text { auto- } \\
\text { matach do gier }\end{array}$ & $\begin{array}{l}\text { Impact of only one ambient scent on money spending } \\
\text { (over three weekends) } \\
\text { Wpływ tylko jednego otaczającego zapachu na wydaną } \\
\text { kwotę (przez trzy weekendy) }\end{array}$ & Hirsch [23] \\
\hline $\begin{array}{l}\mathrm{n}=116 \\
\text { Shoppers } \\
\text { Kupujący }\end{array}$ & $\begin{array}{l}\text { Impact of scents on how customers perceive air quality } \\
\text { and on their moods in shopping mall / Wpływ zapachów } \\
\text { na postrzeganie przez klientów jakości powietrza i na } \\
\text { ich nastroje w centrum handlowym }\end{array}$ & Baron [3] \\
\hline $\begin{array}{c}\mathrm{n}=247 \\
\text { Shoppers } \\
\text { Kupujący }\end{array}$ & $\begin{array}{l}\text { Impact of ambient scents on customers' shopping expe- } \\
\text { riences / Wpływ otaczających zapachów na doświadcze- } \\
\text { nia zakupowe klientów }\end{array}$ & $\begin{array}{l}\text { Mattila and Wirtz } \\
\qquad[31]\end{array}$ \\
\hline $\begin{array}{l}\mathrm{n}=145 \\
\text { Shoppers } \\
\text { Kupujący }\end{array}$ & $\begin{array}{l}\text { Influence of ambient scents on mall shoppers' emotions, } \\
\text { cognition and on their money spending. } \\
\text { Wpływ otaczających zapachów na emocje i poznanie } \\
\text { klientów centrum handlowego oraz ich wydatki }\end{array}$ & $\begin{array}{l}\text { Chebat and } \\
\text { Michon [11] }\end{array}$ \\
\hline $\begin{array}{c}\mathrm{n}=279 \\
\text { Shoppers } \\
\text { Kupujący }\end{array}$ & $\begin{array}{l}\text { Perception towards mall, pleasure and product quality } \\
\text { perception / Postrzeganie centrum, przyjemność oraz } \\
\text { postrzeganie jakości produktów }\end{array}$ & $\begin{array}{l}\text { Michonet et al. } \\
\text { [33] }\end{array}$ \\
\hline $\begin{array}{c}\mathrm{n}=88 \\
\text { Shoppers } \\
\text { Kupujący } \\
\end{array}$ & $\begin{array}{l}\text { Time spent in a selected restaurant and amount of mon- } \\
\text { ey spent therein / Czas przebywania i kwota pieniędzy } \\
\text { wydana w wybranej restauracji }\end{array}$ & $\begin{array}{c}\text { Gueguen and Petr } \\
{[21]}\end{array}$ \\
\hline $\begin{array}{c}\mathrm{n}=134 \\
\text { Undergraduates } \\
\text { Studenci } \\
\text { na 1. stopniu studiów }\end{array}$ & $\begin{array}{l}\text { Soothing impact of scent on anxiety caused by stereo- } \\
\text { types in market } \\
\text { Kojące oddziaływanie zapachu na niepokój spowodo- } \\
\text { wany przez stereotypy na rynku }\end{array}$ & Lee et al. [27] \\
\hline $\begin{array}{l}\mathrm{n}=263 \\
\text { Shoppers } \\
\text { Kupujący }\end{array}$ & $\begin{array}{l}\text { Impact of ambient scent on behaviours of customers, } \\
\text { such as time and money spent } \\
\text { Wpływ otaczającego zapachu na zachowania klientów, } \\
\text { takie jak czas i wydane pieniądze }\end{array}$ & $\begin{array}{c}\text { Morrison et al. } \\
{[36]}\end{array}$ \\
\hline
\end{tabular}

Source / Źródło: the authors' own study / opracowanie własne 
category. The results obtained showed a positive impact of the category-congruent olfactory cue on sales of the product category [25]. There are several field studies, in which there was analyzed the impact of ambient scents on the customers in shopping malls or stores. Generally the research context was focused on money spending, perceiving the environment, evaluating a product or on customer emotions (Tab. 1).

Furthermore, the scent congruency was used in other studies involving stores. The most common types of scents applied were: slight minty lemon and various essential oils in a clothes store $[16,45]$; orange, basil, tea and lemon in a home decor shop; woody, floral, spicy, citrus and food-based aromas in retail stores [26, 28]; lavender and grapefruit scent in a gift store [31], and chocolate scent in a bookstore and café [32]. In the case of shopping mall the most often used scents were lemon, bergamot, orange, grapefruit and cinnamon $[12,46]$. The vanilla scent was utilized in a retail store and it was perceived by consumers as a more feminine smell [36]. Therefore it is suggested to apply gender-incongruent scents, which can help achieve better results and the consumers will perceive experiences, excitement and pleasure in a more positive way [15]. In addition the application of ambient scents and aromatic compounds is popular in other sectors of the business sphere such as restaurants, hotels, post offices or even in the working environment $[30,35]$.

\section{Conclusions}

Based on this reference literature review, there were explored the applications of aromachology in the business sphere including shopping malls, retail stores and other facilities. In various field studies the exposure to scent had a positive impact on the behaviour, mood and emotions of the shoppers or customers. The research context comprised mostly the effects of scents on money spending, product evaluation, perception of environment and overall pleasure, comfort and attitudes of customers towards service environment. The predominantly applied types of scents were floral, citrus, food-based or herbal scents. The final conclusion is that a small change in the environment stemmed from the addition of suitable aromas has definitely a positive impact on customers, thus it has a great potential in various sectors of the business sphere.

\section{Acknowledgement}

The research has been supported by the research grant APVV-17-0564 "The Use of Consumer Neuroscience and Innovative Research Solutions in Aromachology and its Application in Production, Business and Services ". 


\section{References}

[1] Alankin A.: Multisensory Experiential Marketing. [on line]. Eventige Media Group 2016. Access on the Internet [19.10.2018]: https://eventige.com/multisensory-experiential-marketing/

[2] Andreas H., Zidansek M., Sprott D.E., Spangenberg E.R.: The power of simplicity: Processing fluency and the effects of olfactory cues on retail sales. J. Retail., 2013, 89 (1), 30-43.

[3] Baron R.A.: The sweet smell of helping: Effects of pleasant ambient fragrance on prosocial behavior in shopping malls. Pers. Soc. Psychol. B., 1997, 23 (5), 498-503.

[4] Berčík J., Paluchová J., Vietoris V., Horská E.: Placing of aroma compounds by food sales promotion in chosen services business. Potravinarstvo, 2016, 10 (1), 672-679.

[5] Blowman K., Magalhães M., Lemos M.F.L., Cabral C., Pires I.M.: Anticancer properties of essential oils and other natural products. Evid-Based. Compl. Alt. Med., 2018, \#3149362.

[6] Bradford K.D., Desrochers D.M.: The use of scents to influence consumers: The sense of using scents to make cents. J. Bus. Ethics, 2009, 90 (2), 141-153.

[7] Buchbauer G.: Aromatherapy: Use of fragrance and essential oils as medicaments. Flavour Frag. J., 1994, 9, 217-222.

[8] Butcher D.: Aromatherapy - its past and future. DCI, 1998, 162 (3), 22-23.

[9] Chakravarti D., MacInnis D., Nakamoto K.: Product category perceptions, elaborative processing and brand name extension strategies. In: Advances in Consumer Research. Eds. M.E. Goldberg, G. Gorn and R.W. Pollay. Association for Consumer Research, Provo, 1990, vol. 17, pp. 910-916.

[10] Chao-Hsiang W.: Essential oil and aromatherapy. Kexue Nong Ye, 1999, 47 (3), 1-3.

[11] Chebat J.C., Michon R.: Impact of ambient odors on mall shoppers' emotions, cognition, and spending. J. Bus. Res., 2003, 56(7), 529-539.

[12] Chebat J.C., Morrin M., Chebat D.R.: Does age attenuate the impact of pleasant ambient scent on consumer response? Environ. Behav., 2009, 41 (2), 258-267.

[13] De Sousa D.P., Silva R., Silva E., Gavioli E.: Essential oils and their constituents: An alternative source for novel antidepressants. Molecules, 2017, 22 (8),\#1290.

[14] De Sousa D.P.: Analgesic-like activity of essential oils constituents. Molecules, 2011, 16, 22332252.

[15] Doucé L., Janssens W., Leroi-Werelds S., Streukens S.: What to diffuse in a gender-specific store? The effect of male and female perfumes on customer value and behaviour. J. Consum. Behav., 2015, 15(3), 271-280.

[16] Doucé L., Janssens W.: The presence of a pleasant ambient scent in a fashion store: The moderating role of shopping motivation and affect intensity. Environ. Behav., 2013, 45 (2), 215-238.

[17] Farquhar P., Herr P., Fazio R.: A relational model for category extensions of brands. In: Advances in Consumer Research. Eds. M.E. Goldberg, G. Gorn and R.W. Pollay. Association for Consumer Research, Provo, 1990, vol. 17, pp. 856-860.

[18] Fedoroff I., Polivy J., Herman C.P.: The specificity of restrained versus unrestrained eaters' responses to food cues: General desire to eat, or craving for the cued food? Appetite, 2003, 41 (1), 7-13.

[19] Ferriday D., Brunstrom J. M.: "I just can’t help myself": Effects of food-cue exposure in overweight and lean individuals. Int. J. Obes. (Lond)., 2011, 35, 142-149.

[20] Gaillet-Torrent M., Sulmont-Rossé C., Issanchou S., Chabanet C., Chambaron S.: Impact of a nonattentively perceived odour on subsequent food choices. Appetite, 2014, 76, 17-22.

[21] Guéguen N., Petr Ch.: Odors and consumer behavior in a restaurant. Int. J. Contemp. Hosp. M., 2006, 25 (2), 335-339.

[22] Haberland M.: The power of scent: Empirical field studies of olfactory cues on purchase behavior. [on line]. University of St. Gallen 2010. Dostęp w Internecie [10.10.2018]: https://www1.unisg.ch/www/edis.nsf/SysLkpByIdentifier/3735/\$FILE/dis3735.pdf

[23] Hirsch A.R.: Effects of ambient odors on slot-machine usage in a Las Vegas casino. Psychol. Market., 1995, 12 (7), 585-594. 
[24] Islam M.T., da Mata A.M., de Aguiar R.P.S., Paz M.F., de Alencar M.V., Fereira P.M., de Carvalho Melo-Cavalcante A.A.: Therapeutic potential of essential oils focusing on diterpenes. Phyother. Res., 2016, 30 (9), 1420-1444.

[25] Kivioja K.: Impact of point-of-purchase olfactory cues on purchase behavior. J. Consum. Market., 2017, 34 (2), 119-131.

[26] Krishna A., Lwin M.O., Morrin M.: Product scent and memory. J. Consum. Res., 2010, 37 (1), 5767.

[27] Lee K., Kim H., Vohs K.D.: Stereotype threat in the marketplace: Consumer anxiety and purchase intentions. J. Consum. Res., 2011, 38 (2), 343-357.

[28] Leenders M.A.A.M., Smidts A., Haji A.E.: Ambient scent as a mood inducer in supermarkets: The role of scent intensity and time-pressure of shoppers. J. Retailing Consum. Serv., 2016, DOI: 10.1016/j.jretconser.2016.05.007.

[29] Lis-Balchin M.: Aromatherapy science. Pharmaceutical Press, London 2006.

[30] Madzharov A., Ye N., Morrin M., Block L.: The impact of coffee-like scent on expectations and performance. J. Environ. Psychol., 2018, 57. 83-86.

[31] Mattila A.S., Wirtz J.: Congruency of scent and music as a driver of in-store evaluations and behavior. J. Retailing, 2001, 77 (2), 273-289.

[32] McGrath M.C., Aronow P.M., Shotwell V.: Chocolate scents and product sales: A randomized controlled trial in a Canadian bookstore and café. SpringerPlus, 2016, 5(1),\#670.

[33] Michon R., Chebat J.C., Turley L.W.: Mall atmospherics: The interaction effects of the mall environment on shopping behavior. J. Bus. Res., 2005, 58 (5), 576-583.

[34] Moreau C., Markman A., Lehmann D.: "What is it?" categorization flexibility and consumers' responses to really new products. J. Consum. Res., 2001, 27 (4), 489-498.

[35] Morrin M., Ratneshwar S.: Does it make sense to use scents to enhance brand memory? J. Marketing Res., 2003, 40, 10-25.

[36] Morrison M., Gan S., Dubelaar C., Oppewal H.: In-store music and aroma influences on shopper behavior and satisfaction. J. Bus. Res., 2011, 64 (6), 558-564.

[37] Oliveira F.A., Andrade L.N., De Sousa E.B., De Sousa D.P.: Anti-ulcer activity of essential oil constituents. Molecules, 2014, 19, 5717-5747.

[38] Paluchová J., Kleinová K., Berčík J., Horská E.: The perception of merchandising visual components in the fast food restaurants of chosen shopping mall. Proceeding of ICABR X. International Conference on Applied Business Research, Brno, Czech Republic, 2015, September, 14-18, pp. 426437.

[39] Park C., Milberg S., Lawson R.: Evaluation of brand extensions: The role of product feature similarity and brand concept consistency. J. Consum. Res., 1991, 18 (2), 185-193.

[40] Ramaekers M.G., Boesveldt S., Lakemond C.M.M., van Boekel M.A.J.S., Luning P.A.: Odours: Appetizing or satiating? Development of appetite during odor exposure over time. Int. J. Obesity, 2013, 38 (5), 650-656.

[41] Ribeiro-Santos R., Andrade M., de Melo N.R., Sanches-Silva A.: Use of essential oils in active food packaging: Recent advances and future trends. Trends Food Sci. Tech., 2017, 61, 132-140.

[42] Rimkute J., Moraes C., Ferreira C.: The effects of scent on consumer behaviour. Int. J. Consum. Stud., 2015, 40 (1), 24-34.

[43] Rybanská J., Nagyová L., Košičiarová I.: Sensory marketing: Sensory perceptions and emotions as the key factors influencing consumer behaviour and decision-making. In: Marketing Identity. University of Ss. Cyril and Methodius in Trnava, Trnava, Slovak Republic, 2014.

[44] Sobral M.V., Xavier A.L., Lima T.C., de Sousa D.P.: Antitumor activity of monoterpenes found in essential oils. Sci. World J., 2014, \#953451.

[45] Spangenberg E.R., Sprott D.E., Grohmann B., Tracy D.L.: Gender-congruent ambient scent influences on approach and avoidance behaviors in a retail store. J. Bus. Res., 2006, 59 (12), 1281-1287.

[46] Teller C., Dennis C.: The effect of ambient scent on consumers' perception, emotions and behaviour: A critical review. J. Mark. Manage., 2012, 28 (1-2), 14-36.

[47] Tomi K., Fushiki T., Murakami H., Matsumura Y., Hayashi T., Yazawa S.: Relationships between lavender aroma component and aromachology effect. Acta Horticulturae, 2011, 925, 299-306. 
[48] Vernet-Maury E., Alaoui-Ismaïli O., Dittmar A., Delhomme G., Chanel J.: Basic emotions induced by odorants: A new approach based on autonomic pattern results. J. Auton. Nerv. Syst., 1999, 75 (23), 176-183.

[49] Vysekalová J.: Emoce v marketingu. Grada Publishing, Prague 2014, p. 296.

[50] Wang C.X., Chen S.L.: Aromachology and its application in the textile field. Fibres Text. East. Eur., 2005, 54, 41-44.

[51] War A.R., Paulraj M.G., Ahmadetal T.: Mechanisms of plant defense against insect herbivores. Plant Signal. Behav., 2012, 7 (10), 1306-1320.

[52] Whiley H., Gaskin S., Schroder T., Ross K.: Antifungal properties of essential oils for improvement of indoor air quality: A review. Rev. Environ. Health, 2018, 33 (1), 63-76.

[53] Zoon H.F.A., de Graaf C., Boesveldt S.: Food odours direct specific appetite. Foods, 2016, 5 (1), $2-$ 10.

\title{
AROMAKOLOGIA W SEKTORZE ŻYWNOŚCI - ASPEKTY WYBORU PRODUKTÓW ŻYWNOŚCIOWYCH PRZEZ KONSUMENTÓW
}

\author{
Streszczenie
}

Trend w terapii „powrotu do natury” zwiększa znaczenie stosowania olejków aromatycznych i czystych związków zapachowych nie tylko w medycynie, ale też w sferze biznesu. Usługi marketingowe związane z wykorzystaniem zapachów obejmują np. logo zapachowe, czy zapach korporacyjny, dobór zapachu do wnętrz - mocno uzależnionego od branży, zapachy używane w trakcie kampanii marketingowych, imprez czy w punktach sprzedaży oddziałujące na zachowanie klientów. W pracy przedstawiono przeglad literatury na temat zastosowań zapachu w detalicznych punktach sprzedaży produktów żywnościowych. Omówiono oddziaływanie zapachów na zachowania konsumentów, ich emocje i postrzeganie otoczenia, w tym wpływ na prawdopodobieństwo dokonania zakupu, kwotę wydanych pieniędzy oraz ocenę produktów i sklepu. Wykazano pozytywny efekt zastosowanego zapachu na kupujących, na ich nastroje, zachowania i emocje. W odniesieniu do typu zapachu w analizie uwzględniono w większości zapachy kwiatowe oraz na bazie żywności, w tym cytrusowe i ziołowe. Wykazano, że uwzględnienie wskazówek węchowych dla poszczególnych kategorii produktów spożywczych pozytywnie wpływa na sprzedaż całej kategorii produktów. Podsumowując, można stwierdzić, że modyfikacja otoczenia przez dodanie odpowiednich zapachów pozytywnie wpływa na klientów, a to może być dużym potencjałem dla sektora żywnościowego, jak również dla innych sfer biznesu.

Słowa kluczowe: aromakologia, związki aromatyczne, produkty żywnościowe, punkty sprzedaży, zachowania konsumenckie 